\title{
Isolation and Identification of Potent Probiotics with High Lead Removal Capability
}

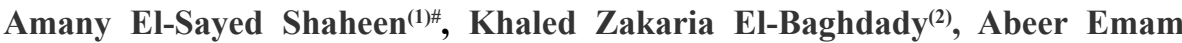 \\ Zakaria $^{(1)}$ \\ (1) Microbiology Department, National Center for Radiation Research and Technology \\ (NCRRT), Egyptian Atomic Energy Authority (EAEA), Cairo, Egypt; ${ }^{(2)}$ Microbiology \\ Department, Faculty of Science, Ain Shams University, Cairo, Egypt.
}

\begin{abstract}
DROBIOTICS play an effective and significant role in human health. The aim of this study was to isolate potential probiotics from Egyptian sources. Among the 14 different bacterial isolates recovered from 8 different sources on Man-Rogosa-Sharp (MRS) agar medium, 5 isolates exhibited tolerance to $\mathrm{pH} 3$ and survived at bile concentration of $0.3 \%$ for $3 \mathrm{~h}$. The selected isolates were resistant to amikacin, vancomycin, ciprofloxacin and bacitracin. In addition, they showed high antibacterial activity against 7 pathogens. Hydrophobicity using xylene and toluene showed high hydrophobic property for $\mathrm{M}$ isolate with toluene and xylene ( $80.43 \pm 0.95 \%$ and $78.2 \pm 0.73 \%$, respectively). The potent isolate was identified by $16 \mathrm{~S}$ rRNA gene as Lactobacillus plantarum strain M (KY508300). This strain was able to remove 71.28 $\pm 0.4 \%$ of lead $(1 \mathrm{mg} / \mathrm{ml})$ after $5 \mathrm{~min}$. The probiotic strain $\mathrm{M}$ showed count stability in yoghurt up to 21 days. The characteristic features of L. plantarum strain $\mathrm{M}$ as potent probiotics entitled it to be used in industrial and environmental applications.
\end{abstract}

Keywords: Probiotics, pH, Antimicrobial, Bile, Hydrophobicity, Lead.

\section{Introduction}

Probiotics are defined by FAO/WHO (2001) as live microorganisms that confer health benefits to the host when administered in adequate amounts (Rafael et al., 2015). There are many beneficial effects attributed to probiotics, including improvement of intestinal health such as prevention of antibiotic-associated diarrhea (AAD), preventing infectious diarrhea, treatment of lactose intolerance and eradication of Helicobacter pylori (Schmid et al., 2006). Other applications of probiotics include enhancement of the immune response, reduction of serum cholesterol, cancer prevention as well as radioprotectors (Khademi \& Abdollhai, 2014).

Probiotics may exert their beneficial effects on the host health through several mechanisms: Adhesion to epithelial cells, colonization, production of biosurfactants, co-aggregation of pathogens, production of antagonistic metabolites (organic acids, hydrogen peroxide, bacteriocins and other inhibitory compounds), competition for nutrients and supporting the immune system (Pellegrino et al., 2018).
Lactic acid bacteria (LAB) are Gram-positive, catalase-negative, oxidase negative, nonsporulating microaerophilic bacteria whose main fermentation product from carbohydrates is lactate and they are important organisms recognized for their fermentative ability as well as their health and nutritional benefits (Gilliland, 1990 and Sablon et al., 2000). Many lactic acid bacteria including; Lactobacillus sp., Bifidobacterium sp., Enterococcus sp., Streptococcus sp., Lactococcus sp., Propionibacterium sp., Pediococcus sp., Leuoconostoc sp., Saccharomyces cerevisiae) are applied in probiotic products (Hatice, 2007). They produce various antimicrobial compounds such as organic acids, di-acetyl, hydrogen peroxide and bacteriocin or bactericidal proteins during lactic fermentations (Lindgren \& Dobrogosz, 1990 and Sablon et al., 2000).

Due to the antimicrobial activities and human health benefits, many lactobacilli were referred as probiotics (Nishida et al., 2016). Lactobacilli exert strong antagonistic activities against many microorganisms, including food spoilage organisms and pathogens (Ogunbanwo et al., 2003 and Malheiros et al., 2015).

\#Corresponding author email: amani.science20@yahoo.com

DOI: 10.21608/ejbo.2018.4532.1190

Edited by: Prof. Dr. Wael S. El-Sayed, Faculty of Science, Ain Shams University, Cairo, Egypt.

(C)2019 National Information and Documentation Center (NIDOC) 
Heavy metals are a unique group of naturally occurring compounds released into the environment by various processes including mining, smelting, Industry, agriculture and many activities generating heavy metals (Thevenon et al., 2011). Lead is one of the abundant heavy metal in the earth. It has a long history of human use in buildings, pipes, sinks, construction projects, batteries, radiation shielding, gasoline and paints (Gorospe \& Gerstenberger, 2008). Lead toxicity cause neurobehavioral problems, mild fatigue, headaches, nausea, vomiting, impaired hemoglobin synthesis, impaired renal function and blindness (Gracia \& Snodgrass, 2007). Lactobacillus sp. was reported to bind and sequester heavy metals via different mechanisms such as ion exchange with peptidoglycan and teichoic acid, precipitation through nucleation reactions and complexation with nitrogen and oxygen ligands (Monachese et al., 2012).

Yogurt is classified as dairy product that is produced by fermentation of lactic acid bacteria. Its production and consumption is growing continuously due to its therapeutic properties beside its high nutritive value. However, there are some studies recorded the poor survival of the probiotics in dairy products during storage and distribution, due to the overly produced lactic acid (Sun \& Griffiths, 2000 and Shima et al., 2012).

This investigation was carried out to isolate probiotic strains with competitive features for industrial applications.

\section{Materials and Methods}

\section{Sampling and isolation}

Natural and commercial yogurt, baby stool, sausage, pickle, cow, sour milk and breast milk samples were collected in sterile screw-capped glass containers and transferred to the laboratory in insulted cooling bag for the microbiological analysis (Sharma et al., 2013; Tulumoglu et al., 2013 and Serrano-Niño et al., 2016). Ten folded dilutions in phosphate buffer saline solution (PBS) were carried out for all samples and then inoculated onto MRS agar plates. The plates were incubated at $37^{\circ} \mathrm{C}$ for $24 \mathrm{~h}$ (Jafari et al., 2011).

\section{Screening isolates for probiotic properties}

Probiotic colonies were counted and purified by re-subculturing on MRS medium. (Ashraf et al., 2009 and Hoque et al., 2010). The pure isolates were tested for the major probiotics criteria including; tolerance to low $\mathrm{pH}$ and bile, antibiotic resistance, the antimicrobial activity and hydrophobicity property.

\section{pH tolerance}

Isolates were evaluated for survival at low $\mathrm{pH}$, as described by Shaikh \& Shah (2013). Overnight active cultures in MRS broth $\left(1.3 \times 10^{9} \mathrm{CFU} / \mathrm{ml}\right)$ were centrifuged for $10 \mathrm{~min}$ at $5000 \mathrm{rpm}$. Pellets were re-suspended in PBS solution adjusted at $\mathrm{pH} 3$ and $\mathrm{pH} 6$ (control) then incubated at $37^{\circ} \mathrm{C}$ for $3 \mathrm{~h}$. After incubation, $1 \%$ of each culture was inoculated into fresh MRS broth (pH 6) then incubated at $37^{\circ} \mathrm{C}$ for $24 \mathrm{~h}$. The growth was measured at $\mathrm{OD}_{600}$.

Isolates that failed to tolerate $\mathrm{pH} 3$ for $3 \mathrm{~h}$, were gradually adapted by successive overnight growing on MRS adjusted at different $\mathrm{pH}$ values; 6, 5, 4 and 3 (Sa'nchez et al., 2007).

\section{Bile tolerance}

Overnight cultures $(10 \mathrm{ml})$ were centrifugation at $5000 \mathrm{rpm}$ for $10 \mathrm{~min}$. The pellets were suspended in MRS broth containing $0.3 \%$ bile and incubated for $3 \mathrm{~h}$ at $37^{\circ} \mathrm{C}$. An inoculum was transferred (1\%) to fresh MRS broth (without bile) then incubated at $37^{\circ} \mathrm{C}$ for $24 \mathrm{~h}$. The growth was measured at $\mathrm{OD}_{600}$ (Shaikh \& Shah, 2013).

Isolates that showed high tolerance for $\mathrm{pH} 3$ and bile for $3 \mathrm{~h}$ were selected for further experiments.

\section{Antibiotic resistance assay}

The selected isolates were tested for their resistance against 14 antibiotics using kirby bauer disc diffusion assay. The studied antibiotics were ampicillin (AM 10 $\mu \mathrm{g}$ ), amikacin (AK

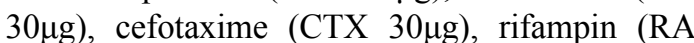
$5 \mu \mathrm{g}$ ), vancomycin (V 30 $\mathrm{g}$ ), trimethoprim/ sulphamethoxazole (SXT 25 $\mu \mathrm{g}$ ), streptomycin (S $10 \mu \mathrm{g})$, erythromycin (E $15 \mu \mathrm{g})$, gentamycin (GM $10 \mu \mathrm{g}$ ), ciprofloxacin (CIP $5 \mu \mathrm{g}$ ), imipenem (IPM

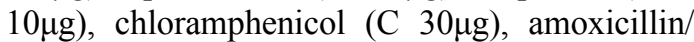

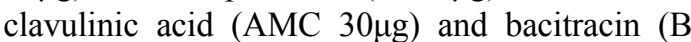

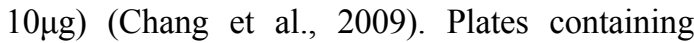
MRS agar medium were inoculated with $1 \mathrm{ml}$ of overnight cultures $\left(1.3 \times 10^{9} \mathrm{CFU} / \mathrm{ml}\right)$. After solidification, antibiotic discs were loaded onto the surface of the media. The plates were left in refrigerator for $2 \mathrm{~h}$ then incubated for $24 \mathrm{~h}$ at $37^{\circ} \mathrm{C}$. The inhibition zones were recorded and tabulated (Amin et al., 2014). 


\section{Antibacterial activity}

Antibacterial activity against different pathogenic bacteria was examined by the agarwell diffusion assay (Cheesbrough, 2000). The tested pathogenic bacteria (Staphylococcus aureus, Streptococcus sp., Pseudomonas sp., Salmonella sp., Proteus sp., E. coli and Klebsiella pneumoni) were kindly supplied from Microbiology Department, Faculty of Science, Ain Shams University. Cell-free supernatants (CFS) of the selected bacterial isolates grown on MRS broth for $24 \mathrm{~h}$ at $37^{\circ} \mathrm{C}$ were centrifuged at $5000 \mathrm{rpm}$ for $15 \mathrm{~min}$. A volume of $200 \mu \mathrm{l}$ of CFS was placed in $12 \mathrm{~mm}$ diameter wells cut into nutrient agar medium. The plates were kept at $4^{\circ} \mathrm{C}$ for $2 \mathrm{~h}$ to allow diffusion then incubated at $37^{\circ} \mathrm{C}$ for $24 \mathrm{~h}$. The inhibition zone was measured after incubation time (Akabanda et al., 2014).

\section{Cell surface hydrophobicity}

Cell surface hydrophobicity of isolates was determined by microbial adhesion to hydrocarbons (MATH) method using xylene and toluene as solvents (Amin et al., 2014). Isolates were grown in MRS broth $\left(1 \% \mathrm{v} / \mathrm{v}\right.$ of $1.5 \times 10^{9}$ $\mathrm{CFU} / \mathrm{ml}$ ) for $24 \mathrm{~h}$ at $37^{\circ} \mathrm{C}$. Cells were collected by centrifugation at $5000 \mathrm{rpm}$ for $15 \mathrm{~min}$, then washed twice by phosphate urea magnesium sulfate (PUM) buffer (Duary et al., 2011) and finally resuspended in the same buffer to achieve initial absorbance $\left(\mathrm{A}_{0}\right) \quad 0.7 \pm 0.02$ at $600 \mathrm{~nm}$. Cell suspension $(5 \mathrm{ml})$ was mixed with $1 \mathrm{ml}$ of hydrocarbon (xylene or toluene) in dry rounded bottom test tubes. The contents were vortexed for $2 \mathrm{~min}$ and left undisturbed for $1 \mathrm{~h}$ at $37^{\circ} \mathrm{C}$ to allow phase separation. The lower aqueous phase was carefully separated with a sterile Pasteur pipette and the absorbance $\left(A_{1}\right)$ was measured at $600 \mathrm{~nm}$. Cell surface hydrophobicity in terms of percent $(\mathrm{H}$ $\%$ ) was calculated using the following equation:

$$
\mathrm{H} \%=\left(1-\mathrm{A}_{1} / \mathrm{A}_{0}\right) \times 100
$$

\section{Identification of potential probiotic isolate by} 16S-rDNA sequencing

Amplification of 16S rRNA gene was performed by a modified method of MassolDeya et al. (1995). A loopful of overnight grown cells was transferred to $50 \mu \mathrm{T}$ TE buffer and boiled for $5 \mathrm{~min}$ then, $1 \mu \mathrm{l}$ of cell suspension was used as template for PCR reaction. PCR was performed using Premix Taq (Ex Taq Version, Takara, Japan) according to instruction manual. A pair of flanking sequences was used for primer binding sites to partially amplify target $16 \mathrm{~S}$ rRNA gene from the bacterial isolates $16 \mathrm{~S} 1 \mathrm{~F}$ (5'-AGAGTTTGATCCTGGCTCAG-3') and 16S 517R (5'-ATTACCGCGGCTGCTGG-3'). Amplification reactions were performed in total volume of $25 \mu \mathrm{l}$ containing $1 \mu \mathrm{l}$ of each primer (10pmol), $12.5 \mu \mathrm{l}$ of Premix Taq and $1 \mu \mathrm{l}$ of DNA. PCR was performed in genius model FGENO2TD thermal cycler (Techne, England). The PCR conditions were adjusted to $5 \mathrm{~min}$ for initial denaturation at $94^{\circ} \mathrm{C}$ then 35 cycles of $1 \mathrm{~min}$ at $94^{\circ} \mathrm{C}, 1 \mathrm{~min}$ at $54^{\circ} \mathrm{C}$ and $1 \mathrm{~min}$ at $72^{\circ} \mathrm{C}$, then finally $10 \mathrm{~min}$ at $72^{\circ} \mathrm{C}$. The amplified genes were run on $1 \%$ agarose gel and visualized by GelDoc. (InGenius 3).

Direct Sequencing of PCR product for 16S rRNA gene was carried out in GATC Company, Sigma. Nucleotide sequence were analyzed using Blastn (Altschul et al., 1997) (http://www.ncbi. nlm.nih.gov/BLAST/) to compare the nucleotide sequence with their similar sequences on the data base. Multiple sequence alignment was performed using ClustalW. Phylogenetic tree was constructed using neighbor-joining method of Saitou \& Nei (1987) with MEGA 6 software (Tamura et al., 2013). Nucleotide sequence was submitted to GenBank to obtain the accession numbers.

Measurement of lead removal by the selected strain

Overnight culture of the selected strain grown on MRS broth was centrifuged at 5000rpm for $5 \mathrm{~min}$ then washed twice with ultra-pure water. Bacterial pellet was resuspended in $2 \mathrm{ml}$ ultra-pure water containing $1 \mathrm{mg} / \mathrm{ml}$ of $\mathrm{Pb}$ (lead acetate). The suspension was mixed thoroughly, and left for $5 \mathrm{~min}$ at room temperature. After that, the tubes were centrifugation for $5 \mathrm{~min}$ at $5000 \mathrm{rpm}$. The supernatants were analyzed by Inductively Coupled Plasma Optical Emission Spectrometer (ICP-OES) (Teledyne Leeman, USA) (Halttunen et al., 2007). Operation condition of ICP-OES was $\mathrm{RF}$ power $1.2 \mathrm{KW}$, coolant gas flow $20 \mathrm{~L} /$ min, auxiliary gas flow $0.3 \mathrm{~L} / \mathrm{min}$, nebulizar gas flow 36psi, solution uptake rate $1 \mathrm{ml} / \mathrm{min}, \mathrm{Mg}$ II/ MgI ration (robustness) 6, replicates 3, integration 10sec.

Yoghurt production and shelf time of the selected strain

Overnight culture of the selected strain was inoculated into sterile cups containing sterile 
Juhayna milk and incubated at $37^{\circ} \mathrm{C}$ for $6 \mathrm{~h}$. The fermented milk (the produced yoghurt) was refrigerated and stored at $4{ }^{\circ} \mathrm{C}$, then the count of probiotic stain was recorded separately at 0,7 , 14 and 21 days. Ten folded serial dilutions of the manufactured yoghurt were prepared. One $\mathrm{ml}$ of each dilution was cultivated on MRS agar plate. All plates were incubated at $37^{\circ} \mathrm{C}$ for $24 \mathrm{~h}$ the count was recorded.

\section{Results}

Isolation and screening of isolates for the probiotic properties

From the 8 sources, 14 bacterial isolates were recovered according to their morphological characteristics on MRS medium. All isolates were screened for the following probiotic properties.

\section{pH tolerance}

The 14 selected bacterial isolates were tested for their tolerance to $\mathrm{pH} 3$. Heavy growth was detected with 5 bacterial isolates $\mathrm{M}, \mathrm{St} 3, \mathrm{Sa} 2, \mathrm{Sa} 3$ and Sa4 (Fig. 1).

\section{Bile tolerance}

The isolates that showed $\mathrm{pH} 3$ tolerance were tested for their tolerance to bile $(0.3 \%)$. All isolates showed bile tolerance, the results were illustrated in Fig. 2. Growth absorbance of the tolerated isolates ranged between $0.760 \pm 0.010$ and $1.093 \pm 0.028$.

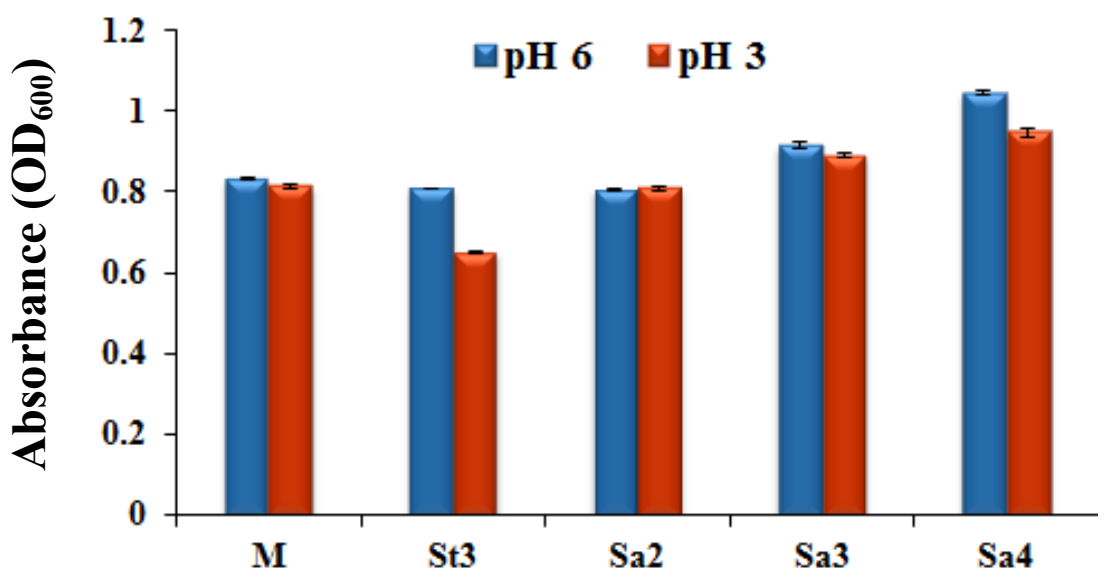

Bacterial isolates

Fig. 1. pH tolerance of the selected bacterial isolates.

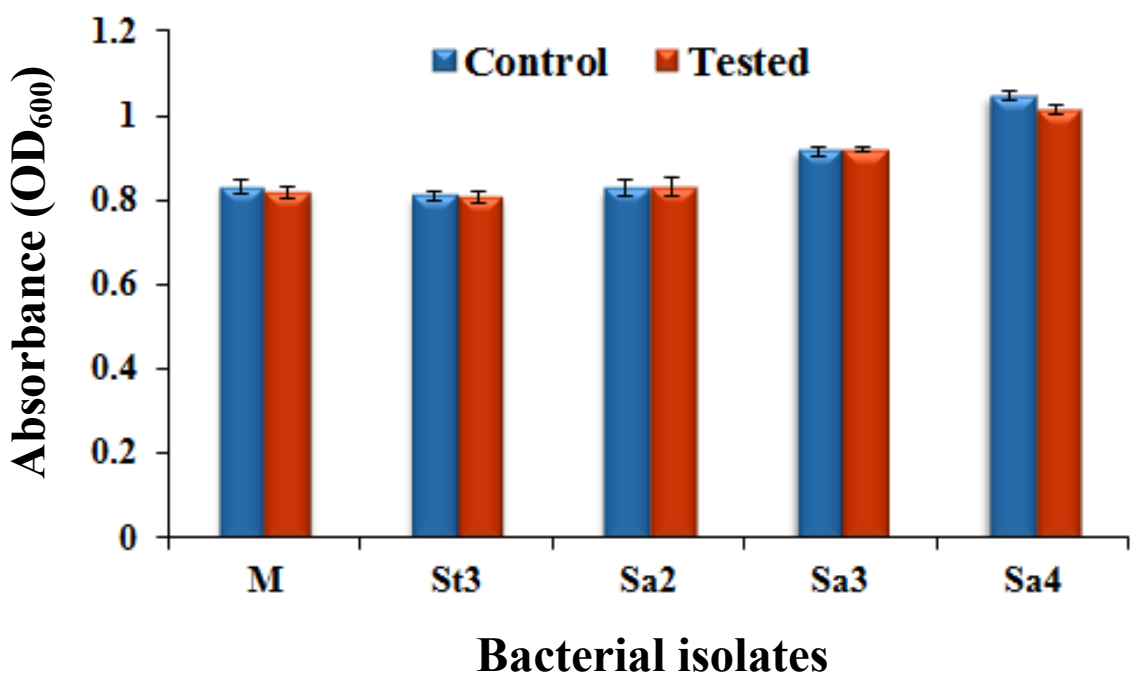

Fig. 2. Bile tolerance of the selected bacterial isolate. 
Antibiotic resistance of the selected isolates

Isolates that showed tolerance towards acidity and bile were tested for their antibiotic resistance against 14 antibiotics. All bacterial isolates were resistant to amikacin, vancomycin, ciprofloxacin and bacitracin while sensitive to rifampin, trimethoprim/sulphamethoxazole, erythromycin, imipenem, chloramphenicol and amoxicillin/ clavulinic acid. Also, isolates St3, Sa2 and $\mathrm{Sa} 4$ share a common resistance towards both streptomycin and gentamycin (Table 1).

\section{Antibacterial activity}

The antibacterial activities of the isolates were examined against 7 pathogenic bacteria (Fig. 3). All supernatants from the bacterial isolates showed inhibitory activity against the tested pathogens. Staphylococcus aureus was the most sensitive pathogen toward the supernatants of all bacterial isolates. Isolate $\mathrm{M}$ was the most potent isolate.

\section{Cell surface hydrophobicity}

Cell surface hydrophobicity of the selected isolates was determined by microbial adhesion to hydrocarbons using xylene and toluene as solvents. The highest hydrophobicity was recorded for $\mathrm{M}$ isolate with both solvents toluene and xylene $(80.43 \pm 0.95 \%$ and $78.2 \pm 0.73 \%$, respectively). While moderate hydrophobicity was detected with xylene for other isolates (Fig. 4).

\section{Identification of the selected probiotic bacterial isolates by $16 \mathrm{~S}$ rRNA gene}

According to the results obtained from previous experiments, isolate $\mathrm{M}$ was selected as the most potent probiotics and identified by 16S rRNA gene as Lactobacillus plantarum ( $L$. plantarum) with $99 \%$ similarity. The nucleotide sequence was submitted to GenBank under accession number KY508300.

Neighbor joining phylogenetic tree of $16 \mathrm{~S}$ rRNA gene was constructed using related members of genus Lactobacillus and Enterococcus durans R03-16 as an out group. The phylogenetic tree revealed that isolate $\mathrm{M}$ was grouped with Lactobacillus plantarum strains with high bootstrap value (91). While other Lactobacillus spp. (Lactobacillus casei 0108, Lactobacillus acidophilus VDLB02 and Lactobacillus pentosus strain TEP12) were separated in another clade with bootstrap value 91 (Fig. 5).

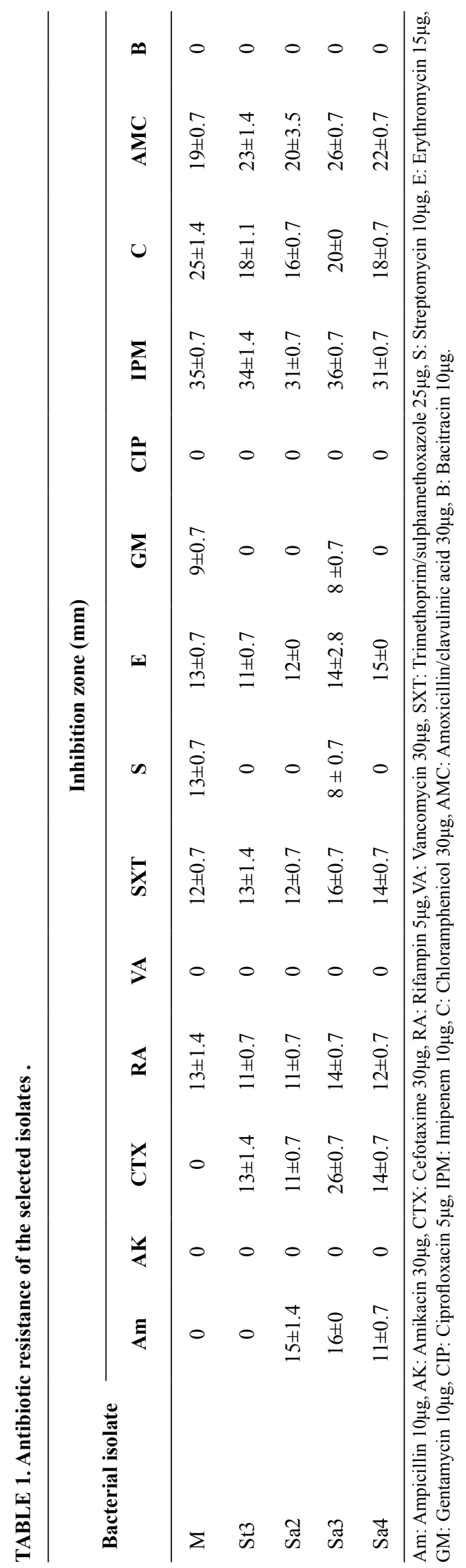

Egypt. J. Bot. 59, No.1 (2019) 


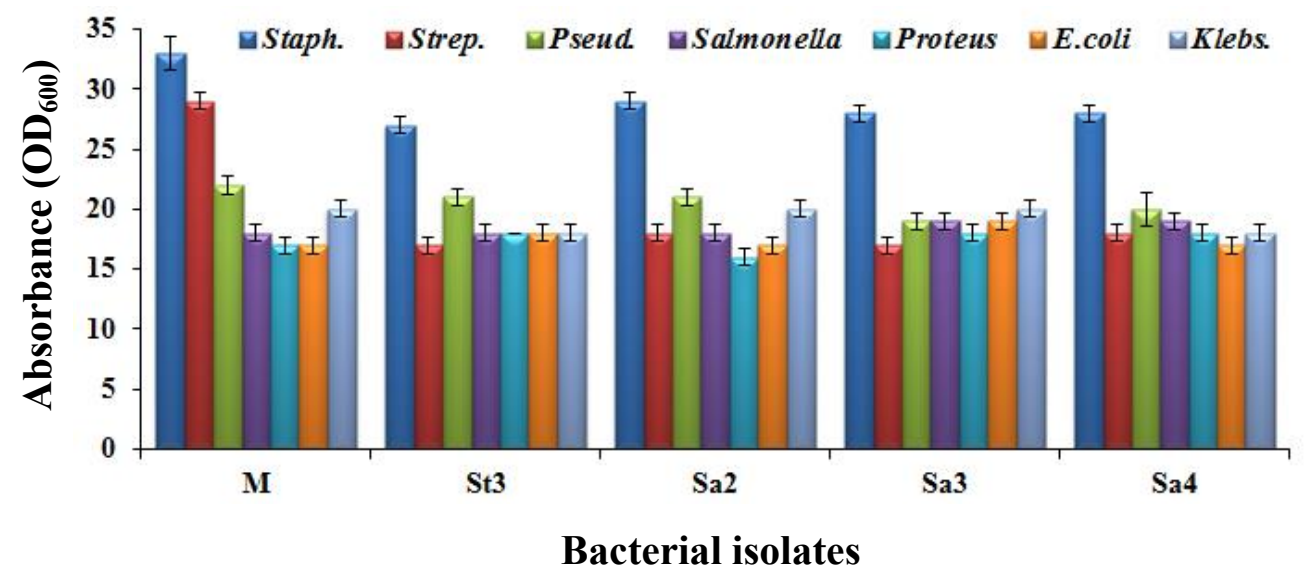

Fig. 3. Antimicrobial activities of the bacterial isolates against some pathogens.

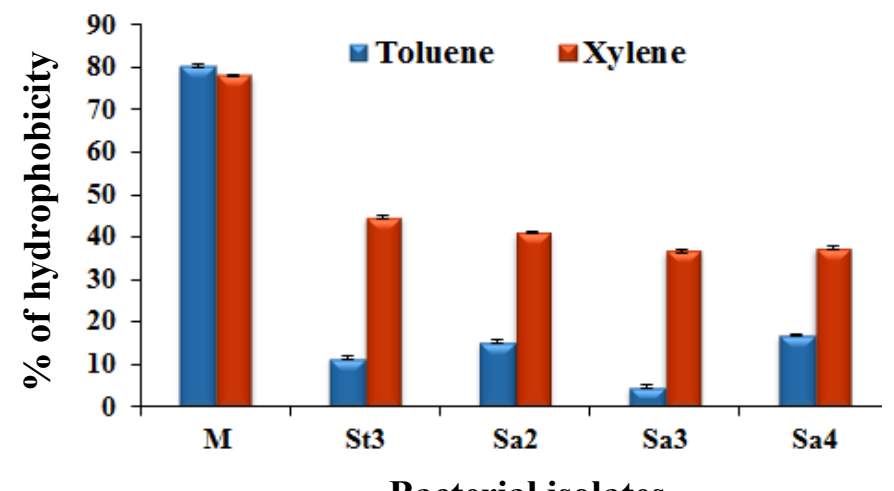

Bacterial isolates

Fig. 4. Hydrophobicity percentages of the selected probiotic isolates using toluene and xylene.

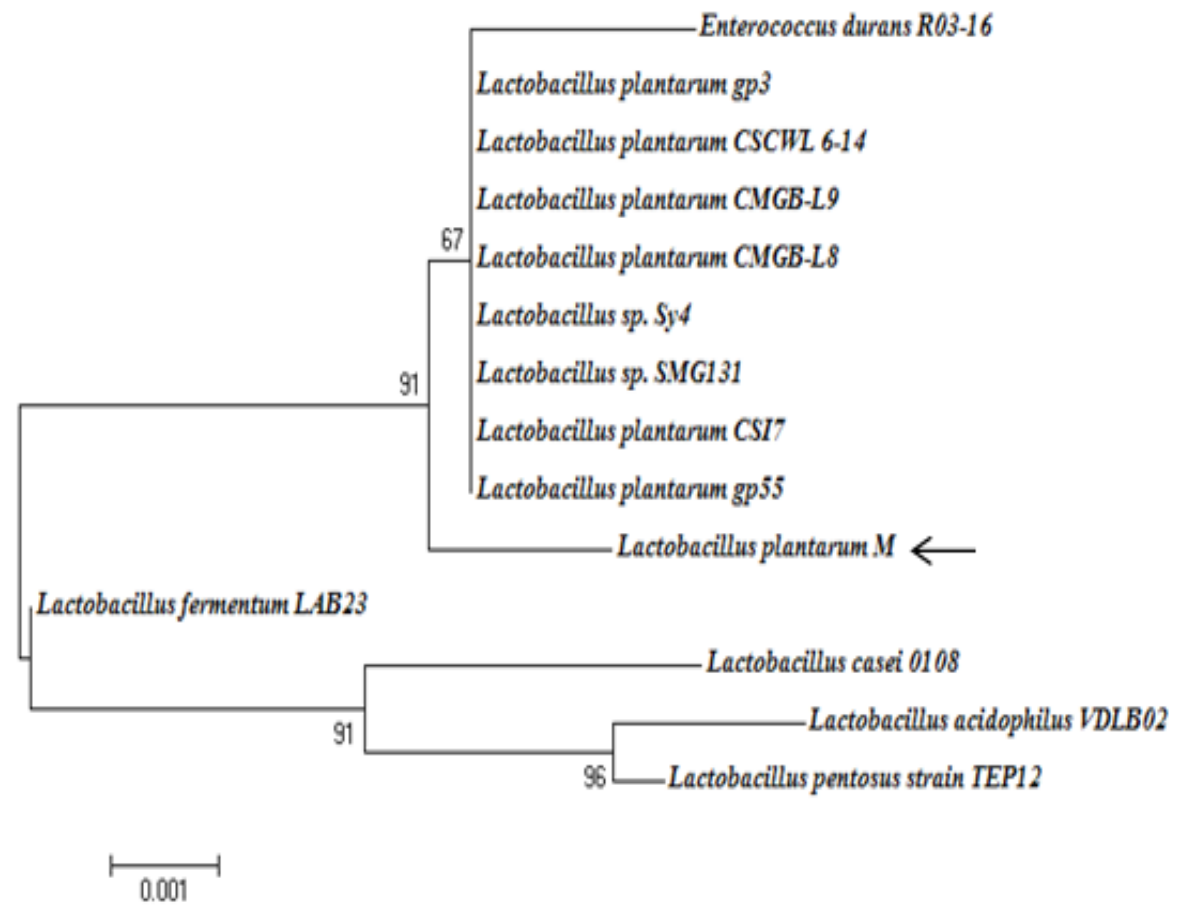

Fig. 5. Neighbor joining phylogenetic tree of $16 \mathrm{~S}$ rRNA genes. The numbers at the nodes are bootstrap values recovered from 100 trees, the bar indicates $0.1 \%$ nucleotide substitution. Arrow indicate the identified strain in this study. 


\section{Lead removal by L. plantarum strain $M$}

The ability of strain $M$ to remove lead was calculated and the percentage of lead removal after $5 \mathrm{~min}$ was $71.28 \pm 0.4$.

\section{Yoghurt production and shelf time of L. plantarum strain $M$}

The ability of L. plantarum strain $\mathrm{M}$ to survive in a product was evaluated after milk fermentation and yoghurt production. The count of strain $\mathrm{M}$ was enumerated after $0,7,14$ and 21 days in the formed yoghurt sample. The probiotic strain showed count stability in formed yoghurt after refrigeration for 7 and 14 while slight decrease started after 21 days (Fig. 6).

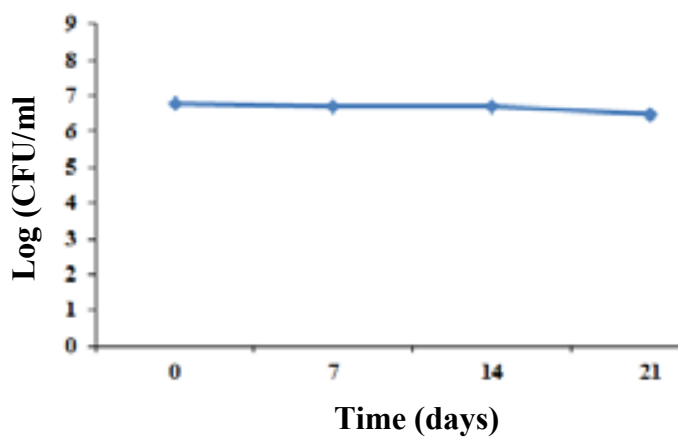

Fig. 6. Shelf time of $L$. plantarum strain $M$ in the manufactured yoghurt sample.

\section{Discussion}

Probiotics were used in many different products worldwide. In addition to food products, probiotics were also used in pharmaceuticals and animal feed. The criteria used for in vitro selection of probiotics, include $\mathrm{pH}$ and bile tolerance that enable them to survive, grow in the gastrointestinal tract (GIT) (Amin et al., 2014).

In this study, 14 bacterial isolates from 8 different sources were grown on MRS agar medium. Only 5 bacterial isolates, M, St3, Sa2, $\mathrm{Sa} 3$ and $\mathrm{Sa} 4$ exhibited high tolerance to $\mathrm{pH} 3$. The survival of isolates in low $\mathrm{pH}$ is very important for bearing initial stress in the stomach ( $\mathrm{pH} 2-3)$ (Jafari et al., 2011). Meanwhile, all isolates grew and survived at bile concentration of $0.3 \%$ for $3 \mathrm{~h}$. This was consistent with Shaikh \& Shah (2013) who demonstrated the tolerance of probiotic isolates to $\mathrm{pH} 3$ and bile $(0.3 \%)$.

The antimicrobial susceptibility as well as antibiotics resistance may serve as suitable criteria for probiotic culture selection (Tulumoglu et al.,
2013 and Curto et al., 2011). The susceptibility of all studied isolates towards different antibiotics was examined by agar disc diffusion method. The selected isolates showed resistance against amikacin, vancomycin, ciprofloxacin and bacitracin while, showed sensitivity against rifampin, trimethoprim/sulphamethoxazole, erythromycin, imipenem, chloramphenicol and amoxicillin/clavulinic acid. This was in accordance with Botes et al. (2008) who reported that L. casei Shirota was inhibited by several commercial antibiotics such as ciprofloxacin, amoxicillin, cefadroxil, roxithromycin, doxycycline and norfloxacin. Lactobacilli are usually sensitive to the cell wall-targeting penicillin and $\beta$-lactamase but resistant to cephalosporins (Gueimonde et al., 2013). Many Lactobacillus species showed a high resistance to vancomycin. Most inhibitors of nucleic acid synthesis seem to have a low inhibitory effect among most Lactobacillus species. On the other hand, lactobacilli were generally susceptible to low concentrations of many protein synthesis inhibitors, such as chloramphenicol and tetracycline due to the presence of their resistant genes that sometimes found in combination with each other (Ammor et al., 2008).

Since probiotic bacteria played a significant role in human health through control of pathogenic strains in the digestive system and improving the immune system (Noori et al., 2016), the antibacterial activity is one of the main features of probiotics. Accordingly, the selected bacterial isolates were tested for their antibacterial activity against seven pathogens; Staphylococcus aureus, Streptococcus sp., Pseudomonas sp., Salmonella sp., Proteus sp., Escherichia coli and Klebsiella pneumonia. The isolates showed high antibacterial activity against all pathogens. This was consistent with Tulumoglu et al. (2013) who observed the antibacterial activity of probiotic isolates against E. coli, $P$. aeruginosa and $S$. aureus. The antibacterial activity of probiotic strains may be due to $\mathrm{pH}$ levels, competition for substrates, the production of substances with a bactericidal or bacteriostatic action, including bacteriocins and bacteriocin-like substances (Pan et al., 2009). The antimicrobial metabolites as a primary metabolic end-product such as lactic acid and acetic acid, diacetyl, hydrogen peroxide, carbon dioxide, aldehydes and other metabolites also act as inhibitory compounds for pathogenic bacteria (Yuksekdag et al., 2004). 
Hydrophobicity is considered a potential probiotic marker along with other criteria for screening of novel probiotic isolates that can adhere to human intestinal cells (Duary et al., 2011). Cell surface hydrophobicity of the selected isolates was performed by MATH method to determine the cell surface characteristics. M isolate showed high hydrophobicity percentage to toluene $(80.43 \pm 0.95 \%)$ and xylene $(78.2 \pm 0.73 \%)$. This hydrophobicity percentage was higher than previously reported by Duary et al. (2011) and Amin et al. (2014) who demonstrated lower hydrophobicity percentages for some Lactobacillus species as 34\% for xylene and 34 to $42 \%$ for toluene.

The most potent probiotic isolates $\mathrm{M}$ was identified by $16 \mathrm{~S}$ rRNA gene as Lactobacillus plantarum strain M (KY508300). Previous reports demonstrated that L. plantarum was isolated from fully ripened, white brined Bulgarian homemade cheeses (Georgieva et al., 2008).

Probiotics have the capacity to bind many toxic heavy metals therefore, was used in bioremediation of environmentally contaminated sites (Srivastava et al., 2012). The concentration used in the present study $(1 \mathrm{mg} / \mathrm{ml})$ exceeds the normal food residue level $(0.01$ to $0.1 \mu \mathrm{g} / \mathrm{ml})$ by 10 folds. The results demonstrated that high capacity of strain $\mathrm{M}$ to remove lead from aqueous solution in short time. The strain $M$ elucidated high removal percentage $(71.28 \pm 0.4)$ of lead in $5 \mathrm{~min}$. Previous report by Yin et al. (2016) demonstrated lower removal percentage $(36.66 \pm 1.01 \%)$ of lead by Lactobacillus plantarum CCFM8661.

The ability of the probiotics to survive in food products is one of the important factors to be considered after addition of the probiotics to food till delivery to consumer gut. Effective probiotics depend on their stability during production, formulation and storage conditions (Noori et al., 2016). Yogurt has been introduced as a safe and healthy food. The shelf life of yogurt was strongly affected by the cell number of lactic acid bacteria (Kim et al., 2009). During storage and distribution, the cell number significantly decreases due to the overproduced lactic acid (Sun \& Griffiths, 2000). In this study, strain M showed stability of the cell number after yoghurt formation and during refrigeration up to 21 days. After that a slight decrease in count was observed which may be due to the lowering in $\mathrm{pH}$ as a result of organic acids production as well as cold storage of yogurt (Kim et al., 2009). The potent Egyptian strain is promising probiotics for industrial and bioremediation applications.

\section{Reference}

Akabanda, F., Owusu-Kwarteng, J., Tano-Debrah, K., Parkouda, C. and Jespersen, L. (2014) The use of lactic acid bacteria starter culture in the production of Nunu, a spontaneously fermented milk product in Ghana. Inter. J. Food Sci. 2014, 1-11.

Altschul, S.F., Thomas, L., Madden, A.A., Schäffer, Z.Z., Miller, W. and Lipman, D.J. (1997) Gapped BLAST and PSI BLAST: A new generation of protein database search programs. Nucleic Acid Res. 25, 3389-3402.

Amin, S., Tale, V.S., Bhadekar, R.K. and Jaiswal, S.N. (2014) Evaluation of effect of non-steroidal antiinflammatory drugs on growth of probiotics. Inter. J. Pure Appl. Sci. Techn. 20, 25-35.

Ammor, M.S., Gueimonde, M., Danielsen, M., Zagorec, M., van Hoek, A.H. and de los ReyesGavilán, C.G., Mayo, B. and Margolles, A. (2008) Two different tetracycline resistance mechanisms, plasmid-carried tet (L) and chromosomally located transposonassociated tet $(\mathrm{M})$, coexist in Lactobacillus sakei Rits 9. Appl. Environ. Microbiol. 74, 1394-1401.

Ashraf, M., Arshad, M., Siddique, M. and Muhammad, G. (2009) In vitro screening of locally isolated Lactobacillus sp. For probiotic properties. Pakistan Vet. J. 29, 186-190.

Botes, M., Van Reenen, C.A. and Dicks, L.M.T. (2008) Evaluation of Enterococcus mundtii ST4SA and Lactobacillus plantarum 423 as probiotics by using a gastro-intestinal model with infant milk formulations as substrate. Int. J. Food Microbiol. 128, 362-370.

Chang, L., Zhang, Z.Y., Ke, D., Jian-Ping, Y. and XiaoKui, G. (2009) Antibiotic resistance of probiotic strains of lactic acid bacteria isolated from marketed foods and drugs. Biomed. Enviro. Sci. 22, 401-412.

Cheesbrough, M. (2000) "District Laboratory Practice in Tropical Countries", Part 2. Cambridge University Press, Cambridge, UK.

Curto, A.L., Mandalari, I.P.G, Dainty, J.R., Faulks, R.M. 
and Wickham, M.S.J. (2011) Survival of probiotic lactobacilli in the upper gastrointestinal tract using an in vitro gastric model of digestion. Food Microbiol. 28, 59-66.

Duary, R.K., Rajput, Y.S., Batish, V.K. and Grover, S. (2011) Assessing the adhesion of putative indigenous probiotic lactobacilli to human colonic epithelial cells. Indian J. Med. Res. 134, 664-671.

Food and Agriculture Organization of the United Nations (FAO), World Health Organization (WHO) (2001) Report of a Joint FAO/WHO Expert Consultation on Evaluation of Health and Nutritional Properties of Probiotics in Food Including Powder Milk with Live Lactic Acid Bacteria.

Georgieva, R.N., Iliev, I.N., Chipeva, V.A., Dimitonova, S.P., Samelis, J. and Danova, S.T. (2008) Identification and in vitro characterisation of Lactobacillus plantarum strains from artisanal Bulgarian white brined cheeses. J. Basic Microbiol. 48, 234-244.

Gilliland, S.E., (1990) Health and nutritional benefits from lactic acid bacteria. FEMS Microbial. Rev. 87, 175-188.

Gorospe, E.C. and Gerstenberger, S.L. (2008) A typical sources of childhood lead poisoning in the United States: A systematic review from 1966-2006. Clin. Toxico. 46, 728-737.

Gracia, R.C. and Snodgrass, W.R. (2007) Lead toxicity and chelation therapy. Ameri. J. Health-System Pharm. 64, 45-53.

Gueimonde, M., Sánchez, B., Clara, G. and Margolles, A. (2013) Antibiotic resistance in probiotic bacteria. Frontiers in Microbio. 4, 202-208.

Halttunen, T., Salminen, S. and Tahvonen, R. (2007) Rapid removal of lead and cadmium from water by specific lactic acid bacteria. Inter. J. Food Microbial. 114, 30-35.

Hatice, Y. (2007) Isolation, characterization, determination of probiotic properties of lactic acid bacteria from human milk, M.Sc. Thesis, School of Engineering and Sciences of Izmir Institute of Technology.

Hoque, M.Z., Akter, F., Hossain, K.M., Rahman, M.S.M., Billah, M.M. and Islam, K.M.D. (2010) Isolation, identification and analysis of probiotic properties of Lactobacillus spp. from selective regional yoghurts. World J. Dairy Food Sci. 5, 39-46.

Jafari, B., Rezaie, A. and Alizadeh, S. (2011) Isolation and identification of potentially probiotic bacteria from traditional dairy products of Ardabil region in Iran. Ann. Biol. Res. 2, 311-317.

Khademi, S. and Abdollhai, H. (2014) Application of hydrogen producing microorganisms in radiotherapy: An idea. Iranian J. Pub. Health, 43, 1018-1019.

Kim, S.H., Lim, C.H., Lee, C. and An, G. (2009) Optimization of growth and storage conditions for lactic acid bacteria in yogurt and frozen yogurt. J. of the Korean Soci. Appl. Biolo. Chem. 52, 76-79.

Lindgren, S.W. and Dobrogosz W.J. (1990) Antagonistic activities of lactic acid bacteria in food and feed fermentation. FEMS Microbiol. Rev. 87, 149-164.

Malheiros, P.S., Sant, V., Brandelli, A. and Franco, B.D.G.M. (2015) Kinetic modeling of thermal inactivation of antimicrobial peptides produced by Lactobacillus sakei subsp. sakei $2 a$. Thermochimica. Acta, 605, 95-99.

Massol-Deya, A.A., Odelson, D.A., Hickey, R.F. and Tiedje, J.M. (1995) Bacterial community fingerprinting of amplified $16 \mathrm{~S}$ and $16-23 \mathrm{~S}$ ribosomal DNA gene sequences and restriction endonuclease analysis (ARDRA). In: "Molecular Microbial. Ecology Manual", 3.3.2, pp. 289-296.

Monachese, M., Burton, J.P. and Reid, G. (2012) Bioremediation and tolerance of humans to heavy metals through microbial processes: a potential role for probiotics? Appl. Environ. Microbiol. 78, $6397-$ 6404.

Nishida S., Ono, Y. and Sekimizu, K. (2016) Lactic acid bacteria activating innate immunity improve survival in bacterial infection model of silkworm. Drug Discov. Ther. 10, 49-56.

Noori, F., Ebrahimi, M.T. and Jafari, P. (2016) Growth optimization of Lactobacillus plantarum T5jq301796. 1, an Iranian Indigenous Probiotic in Lab Scale Fermenter. Appl. Food Biotechnol. 3, 188-193.

Ogunbanwo, S.T., Sanni, A.I. and Onilude, A.A. (2003) Characterization of bacteriocin produced 
by Lactobacillus plantarum $\mathrm{F} 1$ and Lactobacillus brevis OGI. African J. Biotechnol. 2, 219-227.

Pan, X., Chen, F., Wua, T., Tang, H. and Zhao, Z. (2009) The acid, bile tolerance and antimicrobial property of Lactobacillus acidophilus NIT. Food Cont. 20, 598-602.

Pellegrino, M.S., Frola, I.D., Natanael, B., Gobelli, D., Nader-Macias, M.E. and bogni, C.I. (2018) In vitro characterization of lactic acid bacteria isolated from bovine milk as potential probiotic strains to prevent bovine mastitis. Probio. Antimicro. Proteins, https:// doi.org/10.1007/s12602-017-9383-6.

Rafael, C.R.M., Cristina, D.S., Antonio, D.S.V., Martha, L.M.V., Svetoslav, D.T., Susana, M.I.S. and Bernadette, D.G.M.F. (2015) Bacteriocin production and inhibition of Listeria monocytogenes by Lactobacillus sakei subsp. sakei $2 \mathrm{a}$ in a potentially synbiotic cheesespread. Food Microbio. 48, 143-152.

Sa'nchez, B., Champomier-Verge's, M.C., del Carmen Collado, M., Anglade, P., Baraige, F., Sanz, Y., de los Reyes-Gavila'n, C.G., Margolles, A. and Zagorec, M. (2007) Low-pH adaptation and the acid tolerance response of Bifidobacterium longum Biotype longum. Appl. Environ. Microbio. 73, 6450-6459.

Sablon, E., Contreras, B. and Andamme, E.V. (2000) Antimicrobial peptides of lactic acid bacteria: Mode of action, genetics and biosynthesis. Advances in Biochemical Engineering/Biotechnology, 68, 21-60.

Saitou, N. and Nei, M. (1987) The neighbor-joining method: A new method for reconstructing phylogenetic trees. Mol. Biol. Evol. 4, 406-425.

Schmid, K., Schlothauer, R.C., Friedrich, U., Staudt, C., Apajalahti, J. and Hansen, E.B. (2006) Development of probiotic food ingredients. Probiotics in Food Safety and Human Health, 2, 35-66.

Serrano-Niño, J.C., Solís-Pacheco, J.R., GutierrezPadilla, J.A., Cobián-García, A., Cavazos-Garduño, A., González-Reynoso, O. and Aguilar-Uscanga, B.R. (2016) Isolation and identification of lactic acid bacteria from human milk with potential probiotic role. J. Food and Nut. Res. 4, 170-177.

Shaikh, M. and Shah, G. (2013) Determination of probiotic properties of lactic acid bacteria from curd.
Global J. Biol. Agri. Health Sci. 2, 119-122.

Sharma, R., Sanodiya, B.S., Thakur, G.S., Jaiswal, P., Pal, S., Sharma, A. and Bisen, P.S. (2013) Characterization of lactic acid bacteria from raw milk samples of cow, goat, sheep, camel and buffalo with special elucidation to lactic acid production. British Microbiol. Res. J. 3, 743-752.

Shima, A.R., Salina, H.F., Masniza, M. and Atiqah, A.H. (2012) Viability of lactic acid bacteria in home made yogurt containing sago starch oligosaccharides. Int. J. Basic App. Sci. 12, 58-62.

Srivastava, S., Verma, P.C., Singh, A., Mishra, M., Singh, N., Sharma, N. and Singh, N. (2012) Isolation and characterization of Staphylococcus sp. strain NBRIEAG-8 from arsenic contaminated site of West Bengal. Appl. Microbiol. Biotechnol. 95, 1275-1291.

Sun, W. and Griffiths, M.W. (2000) Survival of bifidobacteria in yogurt and simulated gastric juice following immobilization in gellan-xanthan beads. Inter. J. Food Micro. 61, 17-25.

Tamura, K., Stecher, G., Peterson, D., Filipski, A. and Kumar, S. (2013) MEGA6: Molecular evolutionary genetics analysis version 6.0. Mol. Biol. Evol. 30, 2725-2729.

Thevenon, F., Graham, N.D., Chiaradia, M., Arpagaus, P., Wildi, W. and Poté, J. (2011) Local to regional scale industrial heavy metal pollution recorded in sediments of large freshwater lakes in central Europe (lakes Geneva and Lucerne) over the last centuries. Sci. Total Enviro. 412, 239-247.

Tulumoglu, S., Yuksekdag, Z.N., Beyatli, Y., Simsek, O., Cinar, B. and Yaşar, E. (2013) Probiotic properties of lactobacilli species isolated from children's feces. Anaerobe, 24, 36-42.

Yin, R., Zhai, Q., Yu, L., Xiao, Y., Wang, G., Yu, R., Tian, F. and Chen, W. (2016) The binding characters study of lead removal by Lactobacillus plantarum CCFM8661. Eur. Food Res. Technol. 242, 16211629.

Yuksekdag, Z.N., Beyatli, Y. and Aslim, B. (2004)forms of lactic acid bacteria isolated from Turkish kefirs with natural probiotic. LWT/Food Sci. Technol. 37, 663-667.

Received 22/7/2018; accepted $11 / 10 / 2018$ ) 


\title{
عزل وتعريف عزلات بروبيوتيك قوية ذات قدرة عاليه فى التخلص من الرصاص
}

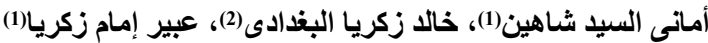

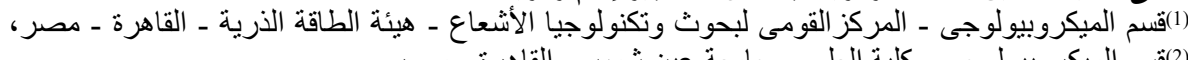

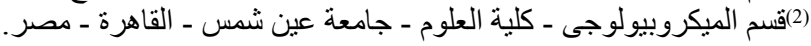

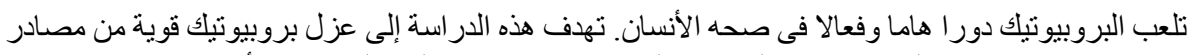

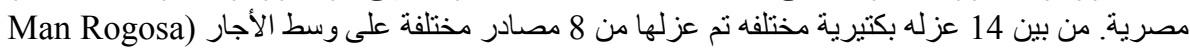

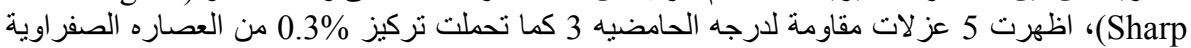

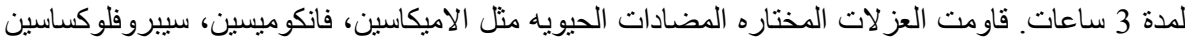

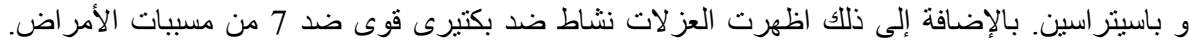

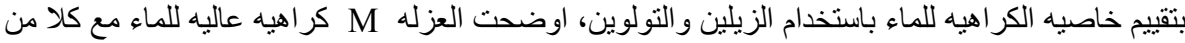

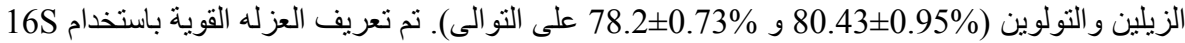
rRNA على انها

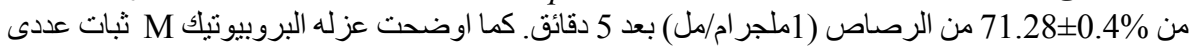

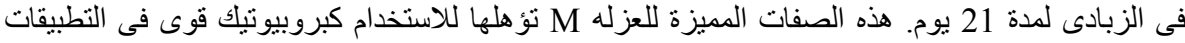

